\title{
Microtensile bond strength of a simplified self-etching adhesive to enamel: influence of multiple coats
}

Resistência adesiva à microtração ao esmalte de um adesivo auto-condicionante simplificado: influência de múltiplas camadas

Fabrício Mezzomo Collares' ${ }^{1}$, Vicente Castelo Branco Leitune ${ }^{2}$, Fabrício Aulo Ogliari ${ }^{3}$, Eduardo Schwartzer ${ }^{4}$, Carmen Beatriz Borges Fortes ${ }^{5}$, Susana Maria Werner Samuel ${ }^{6}$

\section{Resumo}

Este estudo testou a hipótese nula de que o número de camadas de aplicação de um primer autocondicionante pode não influenciar não resistência da interface adesiva resina/esmalte à microtração. Dentes bovinos foram nivelados, para expor os prismas de esmalte, utilizando-se lixa d'água \#600. Os dentes foram divididos em dois grupos: FB 1 camada, FuturaBond (Voco) aplicado de acordo com as recomendações do fabricante por 30s; e FB 4 camadas, aplicadas quatro vezes, 30 s cada. Foram então restaurados com a resina composta fotopolimerizável Polofil (Voco). Após 24 horas, as amostras foram cortadas com um disco diamantado em baixa rotação sob abundante irrigação, para obter palitos de aproximadamente $0,5 \mathrm{~mm}^{2}$ de área. Os palitos foram submetidos à microtração a uma velocidade de $1 \mathrm{~mm} / \mathrm{min}$. A resistência adesiva, em MPa, foi: FB 1 camada, $33.57 \pm 8.77$ (18); FB 4 camadas: 33.57 \pm 8.77 (18). Esses valores, no teste $t$ de student, não apresentaram diferença significativa $(p=0.58)$. Nesse estudo, o número de camadas não interferiu nos valores de resistência de união da interface resina/esmalte.

Palavras-chave: Esmalte dentário, Materiais dentários, Adesivos dentários, Microtração.

\section{Abstract}

This study tested the null hypothesis that the number of applications of a self-etching primer would not influence the microtensile bond strength at the interface resin/enamel. Bovine teeth were flatted to expose the prismatic enamel with wet 600 grit silicon carbide papers. The teeth were divided into two groups: FB 1coat, FuturaBond (Voco) applied according to the manufacturer's instruction for $30 \mathrm{~s}$; and, FB 4coats, applied four times, 30s each. Then, they were restored with Polofil (Voco) resin composite. After 24h, samples were cut with a diamond low speed saw under water cooling to obtain stick-shaped specimens of approximately $0,5 \mathrm{~mm}^{2}$ cross-sectional area. The sticks underwent microtensile testing at a speed of $1 \mathrm{~mm} /$ min. The bond strength, in MPa, was: FB 1coat, $33.57 \pm 8.77$ (18); FB 4coats: $33.57 \pm 8.77$ (18). This values, at $t$ student test, had not showed significant difference $(p=0.58)$. In this study, the number of coats did not interfere at the values of bond strength at the interface resin/enamel.

Keywords: Self-etching primer, Enamel, Microtensile, Bonding agent, Dental materials.
${ }^{1}$ DDS, MS Dr - Fabrício Mezzomo Collares is a PhD student in the Department of Conservative Dentistry at the Federal University of Rio Grande do Sul, Porto Alegre, Rio Grande do Sul, Brazil

${ }^{2}$ DDS, MS - Dr Vicente Castelo Branco Leitune is a PhD student in the Department of Conservative Dentistry at the Federal University of Rio Grande do Sul, Porto Alegre, Rio Grande do Sul, Brazil

${ }^{3} \boldsymbol{D D S}, \boldsymbol{M S}$ - Dr Fabrício Aulo Ogliari is a PhD student in the Department of Opervative Dentistry at the Federal University of Pelotas, Pelotas, Rio Grande do Sul, Brazil

${ }^{4}$ DDS - Dr Eduardo Schwartzer is a MS student in the Department of Conservative Dentistry at the Federal University of Rio Grande do Sul, Porto Alegre, Rio Grande do Sul, Brazil

${ }^{5}$ DDS, MS Dr - Carmen Beatriz Borges Fortes is a Professor in the Department of Conservative Dentistry at the Federal University of Rio Grande do Sul, Porto Alegre, Rio Grande do Sul, Brazil

E-mail: fortes@ufrgs.br

6 DDS, MS, $P h D-D r$ Susana Maria Werner Samuel is a Professor in the Department of Conservative Dentistry at the Federal University of Rio Grande do Sul, Porto Alegre, Rio Grande do Sul, Brazil

E-mail: samuelsp@adufrgs.ufrgs.br

Correspondence: DDS, MS Dr - Fabrício Mezzomo Collares is a PhD student in the Department of Conservative Dentistry at the Federal University of Rio Grande do Sul, Porto Alegre, Rio Grande do Sul, Brazil

Address: Rua Ramiro Barcelos 2492, Laboratório de Materiais Dentários $4^{\circ}$ andar CEP 90035-003 - Porto Alegre - RS

Phone: $+55513308-5198$ or +5551 9361-7955 Fax: $+55513308-5197$ E-mail: fabriciodonto@gmail.com

\section{Introduction}

The enamel acid etching is based on an acid-base reaction that demineralizes hydroxiapatite crystals increasing surface roughness and free energy. Therefore, a better wet of the surface is achieved, leading to tooth substrate adhesion with low viscosity resins (RETIEF et al., 1986; BUSSCHER; RETIEF; ARENDS, 1987; SWIFT; PERDIGÃO; HEYMANN, 1995).

Last decades, adhesive systems have suffered significant evolutions. Since the enamel acid etching (BUONOCORE, 1955) passing through the total acid etching (FUSAYAMA et al., 1979) until nowadays, with the self-etching systems. The surface treatment with self-etching adhesives is based on polimerizable acidic monomers. These high reactive monomers have a phosphoric, a carboxylic or a phosphonic pendant group which are responsible for demineralization of the substrate. Moreover, a methacrylate functional group allows the copolymerization of these molecules with others monomers. Each self-etching adhesive has specific functional monomers which $\mathrm{pH}$ varies from $<1.0$ to 3.0. Thus, achieving a micro-mechanical interlocking with demineralized substrate (DE MUNCK et al., 2005).

Clinically, these systems eliminate the rinsing step simplifying the adhesive restorations protocol. Further, there is a reduced techniquesensitivity making this type of material more easy to use. Self-etching systems are classified according the number of clinical steps: two steps and one step. In the two steps, there are one bottle with the self-etching primer and another with the adhesive resin. Recently, a simplification was done resulting in the all-in-one self-etching adhesive systems which the two bottles are combined and applied at the same time.

In comparison with etch and rinse systems some authors have observed similar performance in dentin (ARMSTRONG et al., 
2003; TOLEDANO et al., 2003). On the other hand, when applied on enamel, one and two steps self-etching systems showed lower bond strength (PASHLEY; TAY, 2001; TAY et al., 2004).

The null hypothesis tested was that multiple coats of an all-in-one self-etching adhesive system have no effect on the micro tensile bond strength to enamel.

\section{Materials and Methods}

Ten lower bovine incisors were stored in distilled water at $4^{\circ} \mathrm{C}$ for less than three months before the test. The teeth had their roots sectioned and their pulp removed. After that, they were mounted in acrylic resin cylinders. Vestibular surface of each tooth used, was previously polished with 600-grit silicon carbide paper under irrigation. Caution was taken to verify superficial defects on the enamel surface with a stereoscope at $40 x$ magnification.

The commercially system used was FuturaBond (Voco, Cuxhaven, Germany), a two bottle one step self etch adhesive (Table 1). One drop of each bottle mixed just before the application. A halogen light-curing unit (3M Curing Light XL 2500, 3M ESPE, St Paul, MN, USA) with light intensity measured by a radiometer (Demetron, Model 100, Danbury, CT, USA) was used. The light intensity was always higher than $500 \mathrm{~mW} / \mathrm{cm}^{2}$. The teeth were divided in two groups. After the adhesive photo-activation, two increments of resin composite (Top Arabesk, Voco, Cuxhaven, Germany) were inserted to cover the enamel surface completely. The increments were photopolymerized for 40 s each.

After storage for $24 \mathrm{~h}$ in distilled water at $37^{\circ} \mathrm{C}$, the specimens were sectioned perpendicular to the bonded interface, with a refrigerated diamond saw at low speed (Isomet, Buehler Ltd, Lake Bluff, IL). Beams with a cross-sectional surface area of approximately $0.5 \mathrm{~mm}^{2}$ for microtensile bond testing were produced. Nine beams of each tooth were produced, resulting in forty-five specimens for group. These beams had their ends fixed to a device for microtensile tests using a cyanoacrylate adhesive. The microtensile test was performed in a universal test machine Emic DL-500 (Emic, São José dos Pinhais, Brazil) at a crosshead speed of $1 \mathrm{~mm} / \mathrm{min}$. Bond strengths were calculated in MPa and analyzed by student $t$ test at the 0.05 level of significance.

The half corresponding to dentin in each specimen was removed from the device and dehydrated in silica gel for $24 \mathrm{~h}$ at room temperature. All specimens were analyzed by a stereoscope at $40 x$ magnification and were classified in agreement with their failure patterns, cohesive in adhesive resin, on adhesive interface, or mixed.

Table 1. Adhesives system used, bonding procedure and manufacturer

\begin{tabular}{|c|c|c|c|}
\hline $\begin{array}{l}\text { Adhesive } \\
\text { System }\end{array}$ & Group & Bonding Procedure & Manufacturer \\
\hline \multirow[t]{2}{*}{$\begin{array}{l}\text { FuturaBond } \\
\text { (1 step - } \\
\text { self-etching } \\
\text { primer) }\end{array}$} & $\begin{array}{l}\text { Control } \\
\text { Group } \\
\text { (FB 1x) }\end{array}$ & $\begin{array}{l}\text { Mix } 1 \text { drop of liquid A and } \\
1 \text { drop of liquid B for } 5 \\
\text { seconds. Apply mixture to } \\
\text { tooth and massage for } 20 \\
\text { seconds. Dry with a faint air } \\
\text { jet for } 5 \text { seconds. Light cure } \\
10 \text { seconds. }\end{array}$ & $\begin{array}{c}\text { Voco, } \\
\text { Cuxhaven, } \\
\text { Germany }\end{array}$ \\
\hline & $\begin{array}{c}\text { Test } \\
\text { Group } \\
\text { (FB 4x) }\end{array}$ & $\begin{array}{l}\text { Mix } 1 \text { drop of liquid } A \text { and } \\
1 \text { drop of liquid B for } 5 \\
\text { seconds. Apply mixture to } \\
\text { tooth and massage for } 20 \\
\text { seconds. Dry with a faint air } \\
\text { jet for } 5 \text { seconds. Repeat } \\
\text { this five times. Light cure } 10 \\
\text { seconds. }\end{array}$ & \\
\hline
\end{tabular}

\section{Results}

\section{Microtensile Bond Strength}

There was no statistically difference between one and four applications $(p=0.58)$ as shown in Table 2 . In the group with one coat the mean was $33,57 \mathrm{MPa}$ and the standard deviation was 8,77 and group with four coats showed similar results, with $35,75 \mathrm{MPa}$ of mean and 8,85 of standard deviation.

The failure mode showed a predominance of mixed failures not showing cohesive failure in enamel (Figure 1). Cohesive resin failure occurs in about $5 \%$ of the specimens of one coat group and $10 \%$ in the four coats group. No specimens were lost in this study, totaling 45 specimens for each group.

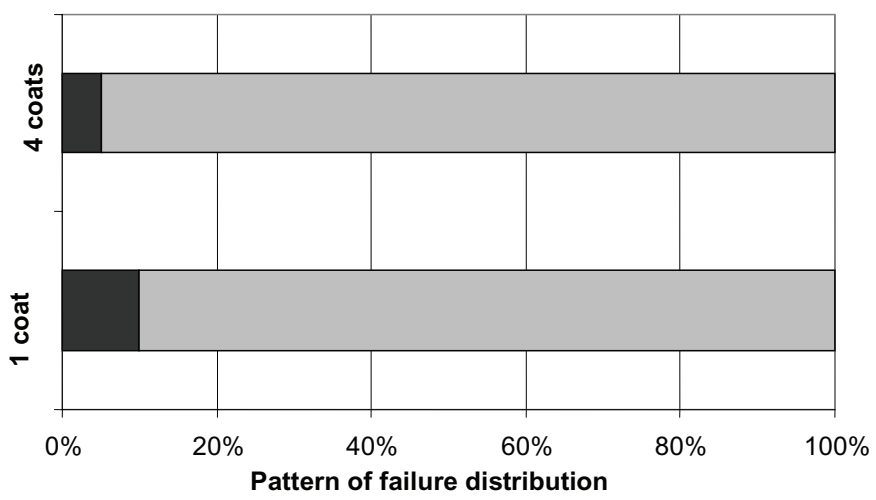

$\square$ Cohesive Resin $\square$ Cohesive Enamel ${ }^{*} \square$ Mixed

* Not observed in this study

Figure 1. Microtensile bond strength and specimens pattern of failure distribution

Table 2. Bond Strength mean values, standard deviation (s.d.) and number of specimens ( $\mathrm{n})$.

\begin{tabular}{lll}
\hline coats (n) & mean, s.d. & $p$ \\
\hline $\mathbf{1}(\mathbf{4 5 )}$ & $33.57 \pm 8.77$ & 0.58 \\
$\mathbf{4}(\mathbf{4 5 )}$ & $35.78 \pm 8.85$ & \\
\hline
\end{tabular}

* Theres is no significant difference at a significance level of $5 \%$.

\section{Discuss ion}

In this study, the bond capacity of a self-etching adhesive system to flattened enamel was evaluated 24 hours after its application. The enamel surface was polished with 600-grit silicon carbide paper to produce a standardized smear layer. The self-etching primer does not remove the smear layer but incorporate it in adhesive/ substrate interface representing a challenge to the acidic monomers demineralization capacity. Microtensile bond strength is a mechanical test that permits a more homogeneous distribution of stress at specimens. Therefore, the nominal bond strength values are higher than other test that utilizes a larger interface area (SANO et al., 1994; PHRUKKANON; BURROW, 1998).

The self-etching adhesive systems were made available in dental market to simplify the restorative protocol and reduce the technique sensitivity. However, some studies showed these adhesives had worse performance than the etch-and-rinse systems when applied in enamel. A study with ground enamel showed microtensile bond strength mean values of $10.3 \mathrm{MPa}$ to the self-etching adhesive, while to the etch-and-rinse it was $49.5 \mathrm{MPa}$ (DE MUNCK et al., 
2003). In other study, the etch-and-rinse adhesive system demonstrated statistical difference to all self-etching adhesives tested. Moreover, examples of samples that were incapable to bond ungrounded substrate was described elsewhere (PERDIGÃO; GERALDELI, 2003). Despite the difficulty to compare absolute means results from different studies, however, the control group mean value here evaluated (33.57 MPa) is close to SingleBond applied to flattened enamel (34,9 MPa) of a previous study (PERDIGÃO; GERALDELI, 2003). Micromorphological studies showed that etched enamel surface with etch-and-rinse systems produces a deeper etching pattern than self-etching systems (PERDIGÃO, 1997; PASHLEY; TAY, 2001; TAY et al., 2004). The self-etching primers produces an incomplete etch at intact enamel when compared to ground substrate which limits the bonding agent infiltration (WEERASINGHE et al., 2007).

The failure pattern was mixed to almost all specimens. Probably, the failure started at adhesive/tooth and/or adhesive/resin interface that has a lower cohesive strength than the substrates (GIANNIN; SOARES; DE CARVALHO, 2004). The absence of cohesive pattern of failures is an indicative of the homogeneity of stress at specimens' interfaces and the mechanical test good performance.

The resinous materials mechanism of bonding to enamel is based on micromechanical interlocking in the roughness surface and the higher contact area created (GWINNETT, 1971; MIYAZAKI, 2000; DE MUNCK et al., 2005). The present study tested more application times of a self-etching system as an alternative to improve mechanical adhesion and increase the bond strength at ground enamel.

A prolonged application time of etch-and-rinse adhesive systems increase the bond strength to dentin (KANCA, 1998; EL-DIN, 2002; CARDOSO et al., 2005; LOGUERCIO et al., 2006). At the self-etching systems, with an increased application times a significant difference at bond strength to dentin (PASHLEY et al., 2002; HASHIMOTO et al., 2004; ITO et al., 2005; HARADA et al., 2006) and a decrease of nanoleakage (HASHIMOTO et al., 2004; ITO et al., 2005) was achieved. However, four coats of the all-in-one adhesive system not showed significant higher bond strength to enamel in this study.

An alternative to achieve better adhesion is the phosphoric acid etching before the application of self-etching primer at enamel (TORIl et al., 2002; ERHARDT; CAVALCANTE; PIMENTA, 2004; VAN MEERBEEK et al., 2004; BRACKETT; BRACKETT; HAISCH, 2006). However, this will increase the number of clinical steps and the technique sensitivity because of the rinsing and drying of the substrate. Adhesive systems with lower $\mathrm{pH}$ could be tested to produce deeper porosities at ground and unground substrate (PERDIGÃO; GOMES; LOPES, 2006).

Despite there were no difference between the tested groups it is not possible to predict the maintenance of bond strength along the time. A higher number of coats produce a thicker layer of adhesive than one single application which could lead to a different degree of hydrolytic degradation. Longitudinally researches are necessary to investigate this hypothesis.

\section{Conclusion}

Based on this study design, the null hypothesis was accepted. Multiple coats of adhesive system did not influence micro tensile bond strength of self-etching adhesive system to enamel.

\section{References}

ARMSTRONG, S. R. et al. Microtensile Bond Strength of a Total-etch 3-step, Total-etch 2-step, Self-etch 2-step, and a Self-etch 1-step Dentin Bonding System Through 15-month Water Storage. J. Adhes. Dent., New Malden, Surrey, v. 5, n. 1, p. 47-56, Spring 2003.
BRACKETT, M. G.; BRACKETT, W. W.; HAISCH, L. D. Microleakage of Class V Resin Composites Placed Using Self-etching Resins: Effect of Prior Enamel Etching. Quintessence Int., Berlin, v. 37, n. 2, p. 109-113, Feb. 2006.

BUONOCORE, M. G. A Simple Method of Increasing the Adhesion of Acrylic Filling Materials to Enamel Surfaces. J. Dent. Res., Chicago, v. 34, n. 6, p. 849-853, Dec. 1955.

BUSSCHER, H. J.; RETIEF, D. H.; ARENDS, J. Relationship Between Surface-free Energies of Dental Resins and Bond Strengths to Etched Enamel. Dent. Mater., Washington, v. 3, n. 2, p. 60-63, Apr. 1987.

CARDOSO, P. et al. Effect of Prolonged Application Times on Resindentin Bond Strengths. J. Adhes. Dent., New Malden, Surrey, v. 7, n. 2, p. 143-149, Summer 2005.

DE MUNCK, J. Microtensile Bond Strengths of One-and Two-step Self-etch Adhesives to Bur-cut Enamel and Dentin. Am. J. Dent., San Antonio, v. 16, n. 6, p. 414-420, Dec. 2003.

DE MUNCK, J. et al. A Critical Review of the Durability of Adhesion to Tooth Tissue: Methods and Results. J. Dent. Res., Washington, v. 84, n. 2, p. 118-132, Feb. 2005.

EL-DIN, A. K.; ABD EL-MOHSEN, M. M. Effect of Changing Application Times on Adhesive Systems Bond Strengths. Am. J. Dent., San Antonio, v. 15, n. 5, p. 321-324, Oct. 2002.

ERHARDT, M. C.; CAVALCANTE, L. M.; PIMENTA, L. A. Influence of Phosphoric Acid Pretreatment on Self-etching Bond Strengths. J. Esthet. Restor. Dent., London, v. 16, n. 1, p. 33-40, 2004. Discussion 41.

FUSAYAMA, T. M. Non-pressure Adhesion of a New Adhesive Restorative Resin. J. Dent. Res., Washington, v. 58, n. 4, p. 1364-1370, Apr. 1979.

GIANNINI, M.; SOARES, C. J.; DE CARVALHO, R. M. Ultimate Tensile Strength of Tooth Structures. Dent. Mater., Washington, v. 20, n. 4, p. 322-329, May 2004.

GWINNETT, A. J. Histologic Changes in Human Enamel Following Treatment with Acidic Adhesive Conditioning Agents. Arch. Oral Biol., Oxford, v. 16, n. 7, p. 731-738, July 1971.

HARADA, T. S. et al. Effect of the Number of Coats of Simplified Adhesive Systems on Microleakage of Dentin-bordered Composite Restorations. J. Contemp. Dent. Pract., Cincinnati, v. 7, n. 5, p. 34-41, Nov. 2006.

HASHIMOTO, M. et al. Effects of Multiple Adhesive Coatings on Dentin Bonding. Oper. Dent., Seattle, v. 29, n. 4, p. 416-423, July/Aug. 2004.

ITO, S. et al. Effects of Multiple Coatings of Two All-in-one Adhesives on Dentin Bonding. J. Adhes. Dent., New Malden, Surrey, v. 7, n. 2, p. 133-141, Summer 2005 .

KANCA, J. Effect of Primer Dwell Time on Dentin Bond Strength. Gen. Dent., Chicago, v. 46, n. 6, p. 608-612, Nov./Dec. 1998.

LOGUERCIO, A. D. et al. A Six-month Clinical Study of a Self-etching and an Etch-and-rinse Adhesive Applied as Recommended and After Doubling the Number of Adhesive Coats. J. Adhes. Dent., New Malden, Surrey, v. 8, n. 4, p. 255-261, Aug. 2006. 
MIYAZAKI, M.; SATO, M.; ONOSE, H.. Durability of Enamel Bond Strength of Simplified Bonding Systems. Oper. Dent., Seattle, v. 25, n. 2, p. 75-80, Mar./Apr. 2000.

PASHLEY, D. H.; TAY, F. R. Aggressiveness of Contemporary Selfetching Adhesives. Part II: Etching Effects on Unground Enamel. Dent. Mater., Washington, v. 17, n. 5, p. 430-444, Sept. 2001.

PASHLEY, E. L. et al. Effects of One Versus Two Applications of an Unfilled, All-in-one Adhesive on Dentine Bonding. J. Dent., Guildford, v. 30, n. 2-3, p. 83-90, Feb./Mar. 2002.

PERDIGÃO, J.; GERALDELI, S. Bonding Characteristics of Selfetching Adhesives to Intact Versus Prepared Enamel. J. Esthet. Restor. Dent., London, v. 15, n. 1, p. 32-41, 2003. [Discussion 42.]

PERDIGÃO, J.; GOMES, G.; LOPES, M. Influence of Conditioning Time on Enamel Adhesion. Quintessence Int., Berlin, v. 37, n. 1, p. 35-41, Jan. 2006.

PERDIGÃO, J. Effects of a Self-etching Primer on Enamel Shear Bond Strengths and SEM Morphology. Am. J. Dent., San Antonio, v. 10, n. 3, p. 141-146, June 1997.

PHRUKKANON, S.; BURROW, M. F. Effect of Cross-sectional Surface Area on Bond Strengths between Resin and Dentin. Dent. Mater., Washington, v. 14, n. 2, p. 120-128, Mar. 1998.

RETIEF, D. H. et al. A Laboratory Evaluation of Three Etching Solutions. Dent. Mater., Washington, v. 2, n. 5, p. 202-206, Oct. 1986.

SANO, H. et al. Relationship between Surface Area for Adhesion and Tensile Bond Strength-evaluation of a Micro-tensile Bond Test. Dent. Mater., Washington, v. 10, n. 4, p. 236-240, July 1994.

SWIFT, E. J.; PERDIGÃO, J.; HEYMANN, H. O. Bonding to Enamel and Dentin: a Brief History and State of the Art, 1995. Quintessence Int., Berlin, v. 26, n. 2, p. 95-110, Feb. 1995.

TAY, F. R. et al. Aggressiveness of Self-etch Adhesives on Unground Enamel. Oper. Dent., Seattle, v. 29, n. 3, p. 309-316, May/June 2004.

TOLEDANO, M. et al. Microtensile Bond Strength of Several Adhesive Systems to Different Dentin Depths. Am. J. Dent., San Antonio, v. 16, n. 5, p. 292-298, Oct. 2003.

TORII, Y. et al. Effect of Phosphoric Acid Etching Prior to Self-etching Primer Application on Adhesion of Resin Composite to Enamel and Dentin. Am. J. Dent., San Antonio, v. 15, n. 5, p. 305-308, Oct. 2002.

VAN MEERBEEK, B. et al. A Randomized, Controlled Trial Evaluating the Three-year Clinical Effectiveness of Two Etch \& Rinse Adhesives in Cervical Lesions. Oper. Dent., Seattle, v. 29, n. 4, p. 376-385, July/Aug. 2004.

WEERASINGHE, D. D. et al. Scanning Electron Microscopy and Energy-dispersive X-ray Analysis of Self-etching Adhesive Systems to Ground and Unground Enamel. J. Mater. Sci. Mater. Med., London, v. 18, n. 6, p. 1111-1116, June 2007. 